Provided for non-commercial research and education use. Not for reproduction, distribution or commercial use.

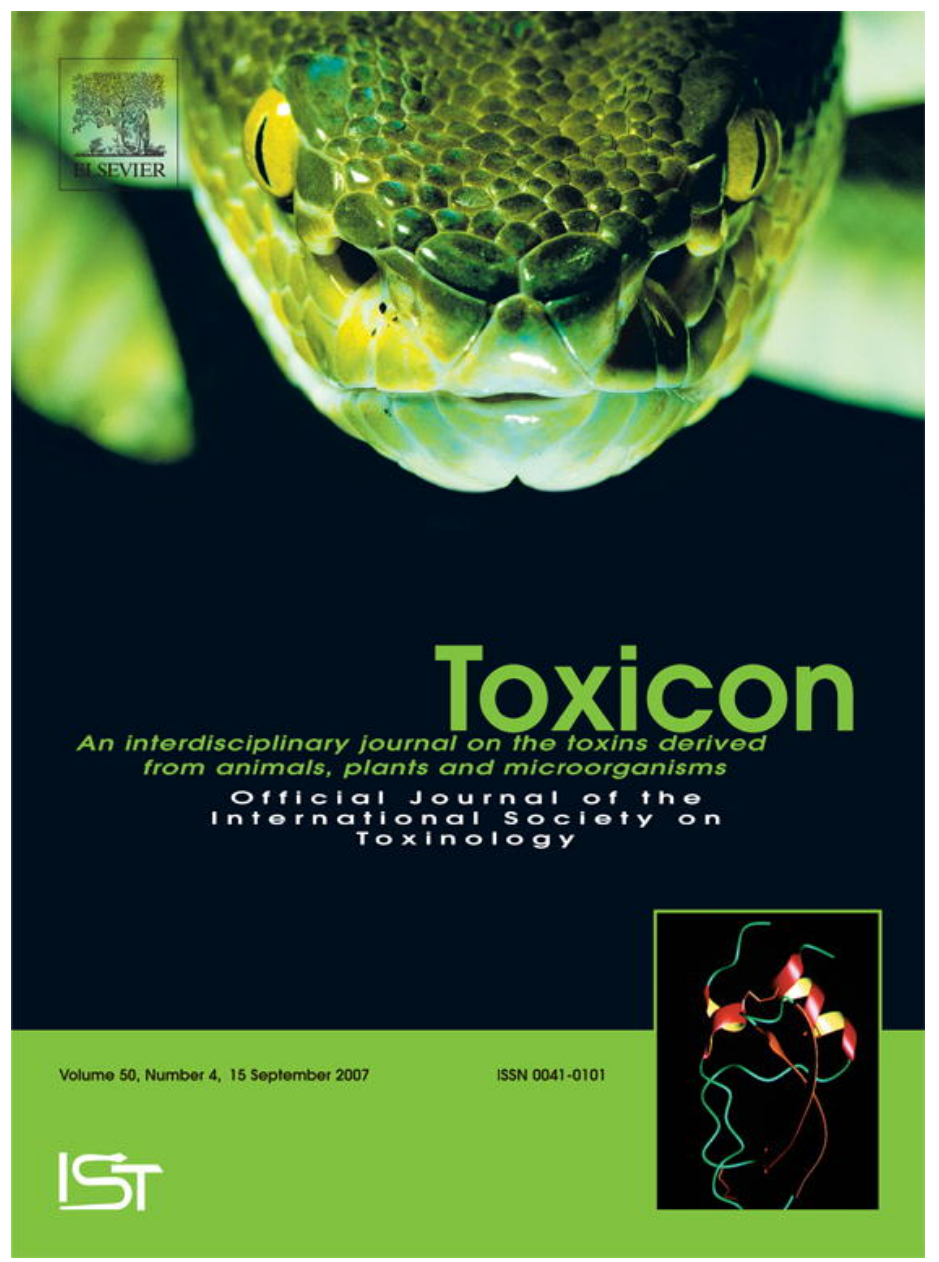

This article was published in an Elsevier journal. The attached copy

is furnished to the author for non-commercial research and education use, including for instruction at the author's institution, sharing with colleagues and providing to institution administration.

Other uses, including reproduction and distribution, or selling or licensing copies, or posting to personal, institutional or third party websites are prohibited.

In most cases authors are permitted to post their version of the article (e.g. in Word or Tex form) to their personal website or institutional repository. Authors requiring further information regarding Elsevier's archiving and manuscript policies are encouraged to visit: 


\title{
Disturbance of voltage-induced cellular calcium entry by marine dimeric and tetrameric pyrrole-imidazole alkaloids
}

\author{
Ulf Bickmeyer $^{\mathrm{a}, *}$, Achim Grube ${ }^{\mathrm{b}}$, Karl-Walter Klings ${ }^{\mathrm{a}}$, Matthias Köck ${ }^{\mathrm{b}}$ \\ ${ }^{a}$ Alfred-Wegener-Institut für Polar- und Meeresforschung in der Helmholtz-Gemeinschaft, Biologische Anstalt Helgoland, Kurpromenade, \\ D-27498 Helgoland, Germany \\ ${ }^{\mathrm{b}}$ Alfred-Wegener-Institut für Polar- und Meeresforschung in der Helmholtz-Gemeinschaft, Am Handelshafen 12, \\ D-27570 Bremerhaven, Germany
}

Received 14 December 2006; received in revised form 23 April 2007; accepted 24 April 2007

Available online 3 May 2007

\begin{abstract}
Twelve brominated pyrrole-imidazole alkaloids from the Caribbean sponges Stylissa caribica and Agelas wiedenmayeri were tested for interactions with cellular calcium homeostasis using PC12 cells. Massadine (half maximal concentration: $5.32 \pm 0.007 \mu \mathrm{M})$, stylissadines $\mathrm{A}(4.48 \pm 1.1 \mu \mathrm{M})$ and $\mathrm{B}(4.6 \pm 1.6 \mu \mathrm{M})$ as well as tetrabromostyloguanidine $(15.6 \pm 0.004 \mu \mathrm{M})$ reduced voltage-dependent calcium entry in PC12 cells as measured with Fura II as calcium indicator. Dibromopalau'amine and mauritiamine reduced voltage-dependent calcium entry but no half maximal concentration can be calculated from our results. Monomeric brominated pyrrole alkaloids such as stevensine, cyclooroidin, oxocyclostylidol, 4-bromopyrrole-2-carboxy-N(E)-lysine, and 4-bromopyrrole-2-carboxyarginine showed no or only minor effects. Ageladine A itself showed fluorescence in a similar range as Fura II and therefore no data are reported here. Based on the results a structure-activity relationship could be established. Absolutely necessary for an activity seem to be a lipophilic (brominated side chain) and a hydrophilic (amino-imidazole core) substructure. The combination of these substructures may be on one hand responsible for the membrane solubility (dibromopyrrole moieties) and on the other hand for the interaction with the hydrophilic area of the calcium channel (amino-imidazole moieties) to accomplish the alkaloids neurotoxic potential.
\end{abstract}

(C) 2007 Elsevier Ltd. All rights reserved.

Keywords: Marine secondary metabolite; Structure-activity relationship; Calcium signal; PC12; Alkaloid; Neurotoxicology; Endocrine; Stylissa; Agelas

\section{Introduction}

Marine organisms represent a source for numerous bioactive and especially neurotoxic compounds as for example conotoxins from cone snails, hunting

\footnotetext{
*Corresponding author. Tel.: + 4947258193224 , fax: +4947258193283 .

E-mail address: Ulf.Bickmeyer@awi.de (U. Bickmeyer).
}

toxins from cnidaria or saxitoxin and tetrodotoxins from several sources (for review, Mebs, 2002). Sponges are known to be a rich source for novel secondary metabolites with diverse biological functions. Several studies have indicated that especially sponges of the families Agelasidae, Axinellidae, and Dictyonellidae defend themselves chemically against fish predators by producing brominated pyrroleimidazole alkaloids (Pawlik et al., 1995; Assmann 
<smiles>N=C(N)NCCC[C@H](NC(=O)c1cc(Br)c[nH]1)C(=O)O</smiles>

4-Bromopyrrole-2carboxyarginine
$\mathrm{Br}$<smiles>Cc1c[nH]c(C(=O)NCCCC[C@H](N)C(=O)O)c1</smiles><smiles>Nc1ncc(C=C2CNC(=O)C3(O)C=C(Br)C(=O)N23)[nH]1</smiles>
4-Bromopyrrole-2carboxy-N(E)-lysine

Oxocyclostylidol<smiles>Nc1ncc(C[C@@H]2CNC(=O)c3cc(Br)c(Br)n32)[nH]1</smiles>

Cyclooroidin<smiles>Nc1ncc(C2=CCNC(=O)c3[nH]c(Br)c(Br)c32)[nH]1</smiles>

Stevensine<smiles>Nc1nc2c(-c3cc(Br)c(Br)[nH]3)nccc2[nH]1</smiles>

Ageladine A<smiles>NC1=NC(=O)C(/C=C/CNC(=O)c2cc(Br)c(Br)[nH]2)(/C=C/c2nc(N)[nH]c2/C=C/CNC(=O)c2cc(Br)c(Br)[nH]2)N1</smiles>

Mauritiamine

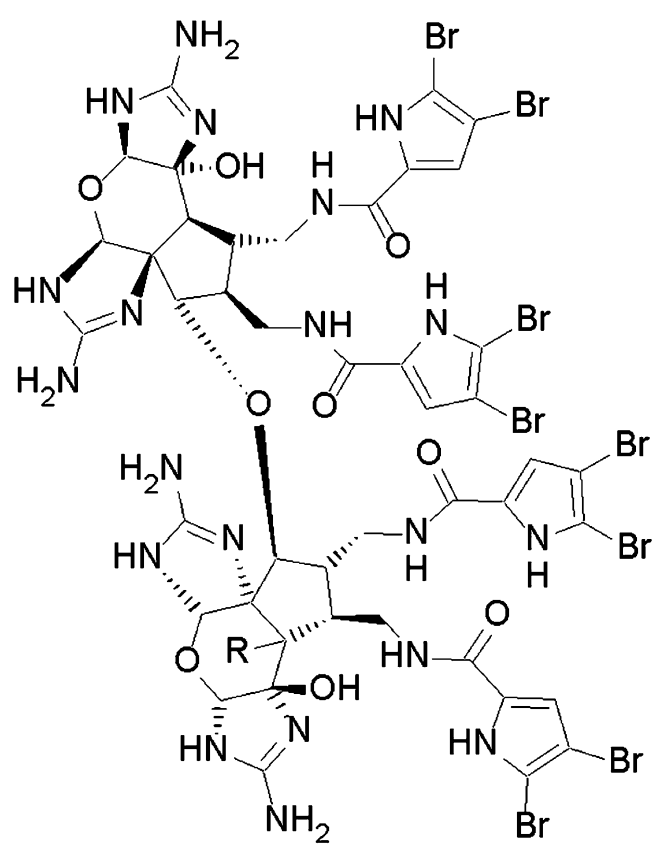

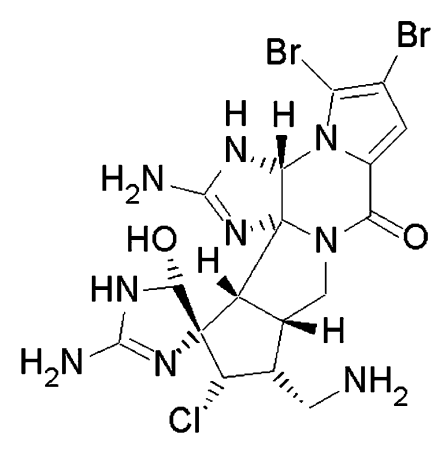

Dibromopalau'amine

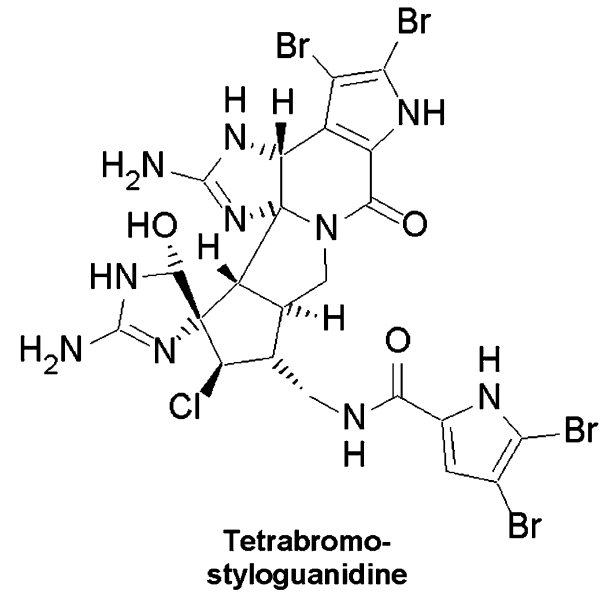

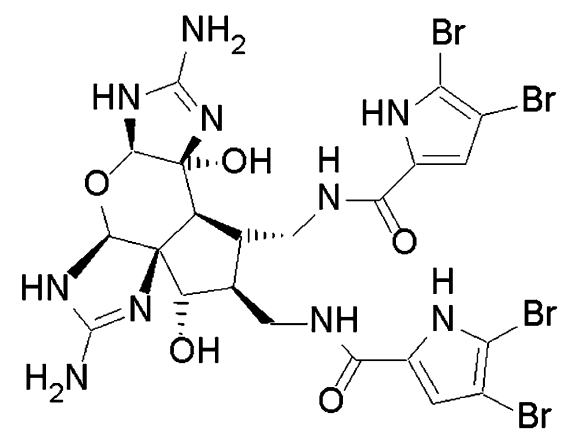

Massadine

Fig. 1. Chemical structure of investigated bromopyrrole alkaloids. 4-Bromopyrrole-2-carboxyarginine, 4-bromopyrrole-2-carboxy-N( $(\varepsilon)-$ lysine, oxocyclostylidol, cyclooroidin, stevensine, and ageladine A are monomeric bromopyrrole alkaloids. Mauritiamine, dibromopalau'amine, tetrabromostyloguanidine, and massadine are dimeric bromopyrrole alkaloids whereas the stylissadines A and B are tetrameric alkaloids. 
et al., 2000, 2004). The feeding deterrent potency of these brominated pyrrole-imidazole alkaloids reflects in part the efficacy of these metabolites to disturb cellular calcium signaling in neuroendocrine PC12 cells, indicating their neurotoxic potential (Bickmeyer et al., 2004; Bickmeyer, 2005). As previously shown, the amino-imidazole group appeared to have a significant effect on voltagedependent calcium elevation (Bickmeyer et al., 2004). The degree of bromination of the pyrrole moiety is another important factor. Some pyrrole-imidazole alkaloids show additionally antibiotic activity (König et al., 1998) even against pathogens like Helicobacter pylori (Urban et al., 1999).

Based on the hypotheses that the grade of bromination as well as the presence of aminoimidazole groups mainly contribute to observed effects, we investigated 12 bromopyrrole alkaloids (Fig. 1), with different structures, grade of bromination and number of amino-imidazol groups, isolated from the marine sponges Stylissa caribica and Agelas wiedenmayeri. The alkaloids 4-bromopyrrole-2-carboxy-N(e)-lysine, 4-bromopyrrole-2-carboxyarginine (Grube et al., 2006), oxocyclostylidol (Grube and Köck, 2006a), stevensine (Albizati and Faulkner, 1985), massadine (Nishimura et al., 2003), tetrabromostyloguanidine (Grube and Köck, 2007; Kobayashi et al. 2007), stylissadines A and B (Grube and Köck, 2006b; Buchanan et al., 2007) (S. caribica), mauritiamine (Tsukamoto et al., 1996), ageladine A (Fujita et al., 2003) (A. wiedenmayeri), and cyclooroidin (Fattorusso and TaglialatelaScafati, 2000; Pöverlein et al., 2006) were used in this study to obtain an insight into the structureactivity relationship of bromopyrrole alkaloids with the cellular $\mathrm{Ca}^{2+}$ homeostasis in PC12 cells.

\section{Material and methods}

\subsection{Experiments using PC12 cells}

\subsubsection{Culture methods}

PC12 cells from the DSMZ (Deutsche Sammlung von Mikroorganismen und Zellkulturen $\mathrm{GmbH}$, Braunschweig, Germany) were kept in culture medium containing RPMI 1640, 10\% fetal calf serum, 5\% horse serum, and 100 units penicillin/ streptomycin per $\mathrm{mL}$. Cells were cultivated in an incubator at $37{ }^{\circ} \mathrm{C}, 90 \%$ humidity and $5 \% \mathrm{CO}_{2}$ with regular medium changes twice a week or when additionally necessary. Cells grew in culture flasks and 1-2 days prior to the experiments were seeded into petri dishes coated with collagen.

\subsubsection{Fluorimetric measurements of intracellular calcium levels}

Cells were incubated in buffer (in mM: $125 \mathrm{NaCl}$, $2.5 \mathrm{KCl}, 1 \mathrm{MgCl}_{2}, 2 \mathrm{CaCl}_{2}, 1.3 \mathrm{NaH}_{2} \mathrm{PO}_{4}, 30$ Glucose, $26 \mathrm{Na}$ HEPES) containing $5 \mu \mathrm{M}$ Fura II acetoxymethylester for $30 \mathrm{~min}$ at room temperature $\left(22 \pm 2{ }^{\circ} \mathrm{C}\right)$. The incubation buffer was removed and cells were washed at least for $20 \mathrm{~min}$. Fluorescence of cells was monitored by an imaging system (Visitron, Puchheim) and a CCD camera mounted on an inverted microscope (Zeiss Axiovert 100). About 30 PC12 cells were measured simultaneously, separated using "the region of interest" function of the software (Metafluor, Meta Imaging Series). Fluorescence was obtained through an UV objective (Zeiss NeoFluar $20 \times$ ). Data were obtained by division of two images, one obtained at $340 \mathrm{~nm}$ and the other at $380 \mathrm{~nm}$ excitation. For determination of $R_{\min }$ and $R_{\max }$, cells were loaded with Fura II and were exposed to $10 \mu \mathrm{M}$ ionomycin to permeabilize the membrane for $\mathrm{Ca}^{2+}$; for determination of $R_{\max }$ we used usual buffer and for determination of $R_{\min }$ in calibration experiments buffer without $\mathrm{CaCl}_{2}$ but with additional $10 \mathrm{mM}$ EGTA. Fluorescence ratios were converted into calcium concentrations by the formula given by Grynkiewicz et al. (1985). Pyrrole alkaloids were stored at $50-100 \mathrm{mM}$ stock solutions in methanol at $4{ }^{\circ} \mathrm{C}$ for experimental use, otherwise as freeze-dried powder at $-20^{\circ} \mathrm{C}$.

\subsubsection{Experimental design}

The recording chamber, mounted on a microscope had a volume of $2 \mathrm{~mL}$ and the peristaltic pump was adjusted to $4 \mathrm{~mL} / \mathrm{min}$; exchanging the chamber volume in $30 \mathrm{~s}$. To depolarize the cells, $80 \mathrm{mM} \mathrm{KCl}$ was used (supplemented for $80 \mathrm{mM}$ $\mathrm{NaCl}$ ) in the experimental buffer. The depolarization of the cellular membrane potential therefore increased gradually during $30 \mathrm{~s}$ of perfusion. Cells were depolarized three times for 1 minute during the course of a single experiment with the duration of about $60 \mathrm{~min}$. Usually 30 cells were measured simultaneously. Vehicle control experiments using methanol, the solution solvent of alkaloids, showed no effect at concentrations lower then $1 \%$. By using stock solutions of $50-100 \mathrm{mM}$ much lower concentrations of methanol were applied during the experiments. Results are presented as the mean \pm SEM, unless otherwise stated. Statistics and 
calculations were performed using computer software Prism (Graphpad) and Igor (WaveMetrics).

\subsubsection{Sponge secondary metabolites and chemicals}

The investigated bromopyrrole alkaloids (Fig. 1) were isolated from dichloromethane/methanol extracts of the Caribbean sponges $A$. wiedenmayer $i$ and $S$. caribica using previously reported methods of collection, isolation and structure elucidation (Grube and Köck, 2006a,b). Cyclooroidin was synthesized by T. Lindel, TU Braunschweig. Other chemicals were obtained from Sigma, Merck, Fluka and Molecular Probes.

\section{Results}

The bromopyrrole alkaloids (Fig. 1) were tested in a series of experiments, applying $10 \mu \mathrm{M}$ of each compound to test for their efficacy to interact with cellular calcium signaling. The compounds may change intracellular calcium levels without a cellular stimulation or may interfere with stimulus-induced calcium level changes. As a stimulus we chose a depolarization of cells using high potassium solution $\left(\mathrm{K}^{+}\right)$, which can be repeated several times without an alteration in induced signals (Bickmeyer et al., 2005). Alkaloids which showed an effect were investigated more deeply in respect to a possible dose-response relationship of observed effects.

Stevensine, 4-bromopyrrole-2-carboxyarginine (Fig. 2A), 4-bromopyrrole-2-carboxy-N(E)-lysine, oxocyclostylidol and cyclooroidin showed no detectable effect applied in a concentration of $10 \mu \mathrm{M}$ $(n=3)$. To verify this, we tested the alkaloids again in the concentration of $100 \mu \mathrm{M}$ and the most substances showed no obvious effect related with voltage-dependent calcium entry (summarized in Fig. 3). For unknown reasons, an immediate drop of fluorescence signals was measured after application of $100 \mu \mathrm{M}$ cyclooroidin; this compound was at $10 \mu \mathrm{M}$ concentrations without any effect, therefore it is not included in later analysis. Ageladine A seemed to affect the depolarization-induced calcium elevation, but showed a strong fluorescence itself at $500 \mathrm{~nm}$ wavelength following excitation with UV light, which is used to excite the calcium dye Fura II. Therefore, we refused to measure dose-response curves of ageladine A due to its inherent fluorescence during UV excitation.

Massadine, stylissadines $\mathrm{A}$ and $\mathrm{B}$, tetrabromostyloguanidine (Fig. 2B-E), dibromopalau'amine, and mauritiamine were effective in reducing vol- tage-dependent calcium entry. Stylissadine A (half maximal concentration $4.48 \pm 1.1 \mu \mathrm{M}$; Hill coefficient, $N=1.39)$ and stylissadine B $(4.6 \pm 1.6 \mu \mathrm{M}$; $N=2.33)$ were the most potent substances in this respect followed by massadine $(5.32 \pm 0.007 \mu \mathrm{M}$, $N=3.59$ ). Besides its slightly different potency, the major difference between massadine on one hand and stylissadines $\mathrm{A} / \mathrm{B}$ on the other hand, was the reversibility of its effect. The reduction of voltage-dependent calcium entry was not reversible after washout for both stylissadine compounds (Fig. 2C-E). After application of the high concentration of $100 \mu \mathrm{M}$ the effect of massadine was still partly reversible, but both stylissadine compounds eliminated depolarization-induced calcium entry followed by an increase of intracellular calcium (Fig. 2D, E). The calcium source of the calcium increase is not clear, but such a long lasting strong increase should involve calcium entry from the extra cellular solution. To address this issue we blocked L-type channels with nifedipine and $\mathrm{N}$-type channels with $\omega$-conotoxin without an alteration in the increase of intracellular calcium. The cells show mainly L-type $(67 \pm 27 \%)$ and N-type currents $(30 \pm 10 \%)$ (Hassenklöver and Bickmeyer 2006) and some cells a small fraction of P-type channels. A blockade of calcium extrusion mechanisms may be a reason for the described calcium increase and/ or a depletion of intracellular calcium stores followed by calcium entry. There was no membrane damage to be recognized nor loss of dye. In addition, Grube and Köck (2006b) described stylissadines $\mathrm{A}$ and $\mathrm{B}$ to be not cytotoxic and to have no antibacterial effect.

Tetrabromostyloguanidine and mauritiamine were less potent but nevertheless tetrabromostyloguanidine elimimated voltage operated calcium entry at $100 \mu \mathrm{M}$ showing a half maximal concentration of $15.6 \pm 0.04 \mu \mathrm{M} \quad(N=2.71)$. Mauritiamine and dibromopalau'amine reduced voltage operated calcium entry but the maximal concentration should be far exceeding $100 \mu \mathrm{M}$ as shown in Fig. 3 summarizing the data of the obtained doseresponse relationships.

\section{Discussion}

Bromopyrrole alkaloids interact with the cellular calcium homeostasis by reducing voltage-dependent calcium elevation (Bickmeyer et al., 2004) and do not interact with store operated calcium entry (Bickmeyer, 2005) as has been described for the 
A

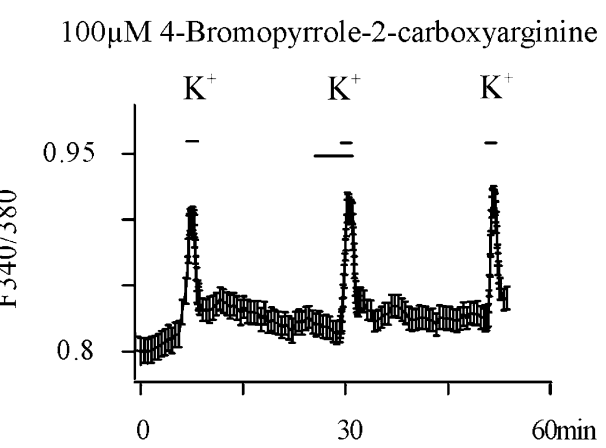

C

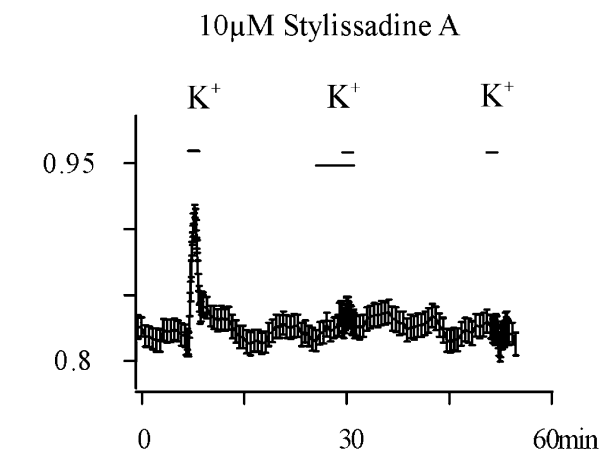

E

$100 \mu \mathrm{M}$ Stylissadine B

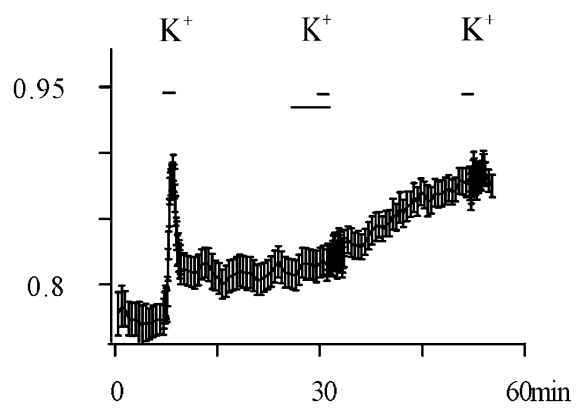

B

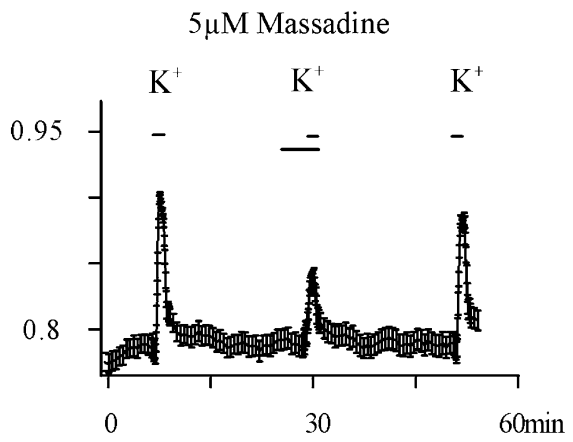

D

$100 \mu \mathrm{M}$ Stylissadine A

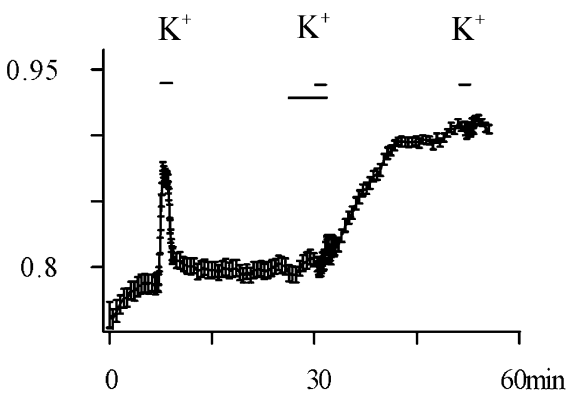

F

$100 \mu \mathrm{M}$ Tetrabromostyloguanidine

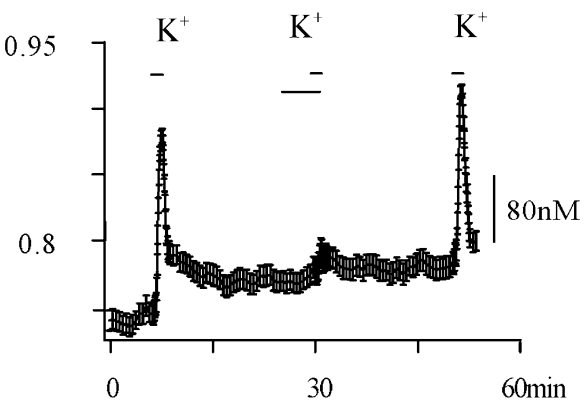

Fig. 2. Effects of indicated alkaloids on voltage-dependent calcium entry. Intracellular calcium levels are represented as F340/380 (scale bar in F). (A-F) Averaged fluorescence ratio traces each of about 30 cells. These traces represent a single experiment consisting of control depolarization $\left(\mathrm{K}^{+}\right)$, application of alkaloid (concentration and alkaloid as indicated) followed by $\left(\mathrm{K}^{+}\right)$and wash followed by $\left(\mathrm{K}^{+}\right)$.

algal secondary metabolites 2,4-dibromophenol and 2,4,6-tribromophenol (Hassenklöver et al., 2006).

Due to the slightly varying structures of the tested dimeric alkaloids (e.g. massadine and tetrabromostyloguanidine) a structure-activity relationship could be established. Dimeric alkaloids containing non-cyclized dibromopyrrole moieties (e.g. massadine) are the most active compounds in our calcium assay. Absolutely necessary for an activity seem to be a lipophilic (brominated side chain) and a hydrophilic (amino-imidazole core) substructure (see Fig. 4). The combination of these substructures may be on one hand responsible for the membrane solubility (dibromopyrrole moieties) and on the other hand, for the interaction with the hydrophilic area of the calcium channel (amino-imidazole moieties). Another limiting factor is the molecule size of pyrrole-imidazole alkaloids. Dimeric alkaloids are potent reversible calcium channel blocker whereas the tetrameric molecules stylissadines A and B show a strong but a non-reversible effect. The high grade of bromination indicates a high lipophilicity of this compounds which in part may be responsible for the non-reversibility by washout. Monomeric pyrrole-imidazole alkaloids are less or non-active. The missing amino-imidazole moiety in 
A

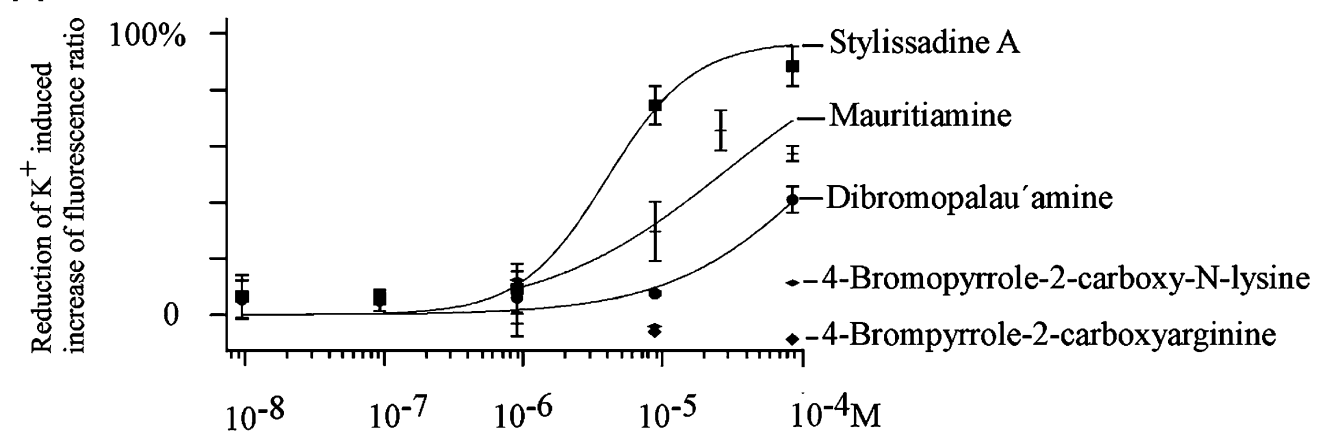

B

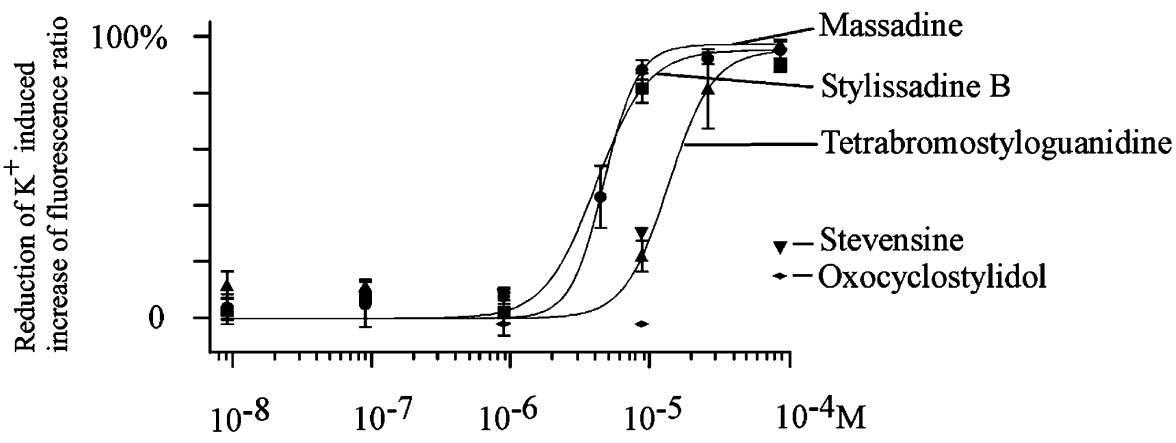

Fig. 3. Normalized dose-response relationships of pyrrole-imidazole alkaloids (A, B). The data $(n \geqslant 2 \pm$ SEM) were fitted using the Hill equation.

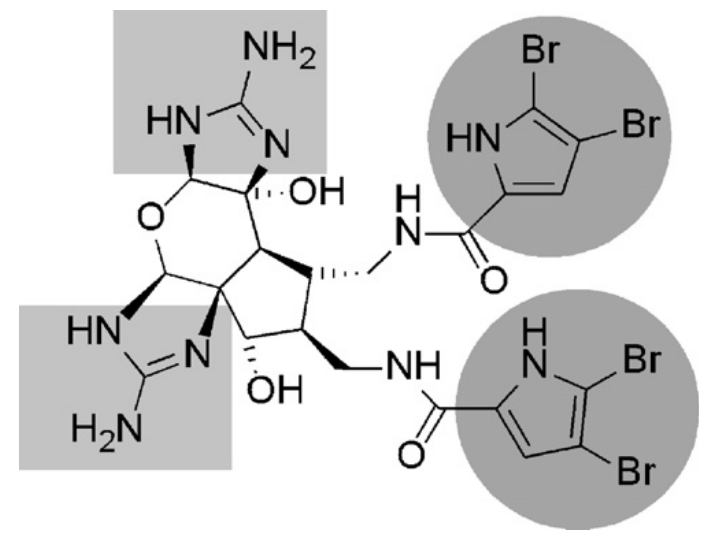

Fig. 4. Massadine as model for pharmacophores concerning the blockade of calcium channels of PC-12 cells. The lipophilic side chains are marked by circles whereas the hydrophilic guanidine moieties are marked by rectangles.

4-bromopyrrole-2-carboxy-N(e)-lysine and 4-bromopyrrole-2-carboxyarginine and only one bromine atom may explain the lack of activity. Oxocyclostylidol is the first pyrrole-imidazole alkaloid isolated from natural sources containing a twiceoxidized pyrrole moiety. The more hydrophilic pyrrole moiety may be the reason for the inactivity under experimental conditions. Stevensine was the only tested monomeric alkaloid with an intact dibromopyrrole moiety but a cyclized structure.
The order of potency of pyrrole-imidazole alkaloids in the present work partly corroborates our previous results with pyrrole-imidazole alkaloids, where higher bromination and the aminoimidazole groups seem to be responsible for reported effects on voltage-dependent calcium entry (Bickmeyer et al., 2004; Bickmeyer, 2005).

The hydrophilic guanidine moieties seem to be of importance for the efficacy of toxins. Two guanidine moieties are present in saxitoxin, which blocks sodium as well as in part calcium channels (Llewellyn 2006). Bricelj et al. (2005) showed the significance of a single amino-acid mutation between transmembrane $\alpha$-helices 5 and 6 for reduced sensitivity of clam sodium channels to the binding of saxitoxin. A guanidine moiety is found as well in the neurotoxin tetrodotoxin, which also blocks sodium channels at binding sites between the transmembrane domains 5 and 6 (for review, Catterall et al. 2007). Calcium and sodium channels are closely related and structurally very similar. The brompyrrole alkaloid dibromosceptrin includes two guanidine moieties and does not only block calcium (Bickmeyer et al. 2004) but also sodium ion channels (Rivera-Rentas et al. 1995). The guanidine groups included in the tested bromopyrrole alkaloids may also be responsible for binding at the loop 
between transmembrane $\alpha$-helices 5 and 6 of the calcium channels.

The biological relevance of the substances may be its antifeeding activity as reported from Pawlik et al. (1995), Chanas et al. (1996) and Assmann et al. (2000) for several pyrrole-imidazole alkaloids, which partly overlaps with its potency to disturb calcium signals (Bickmeyer et al., 2004) or its antibiotic potency (Bernan et al. 1993). A disturbance of cellular signaling in exposed cells as chemoreceptive cells in related organs may induce a deterrent effect for more than one predator species as a potentially generalized mechanism. The potency of the alkaloids to disturb voltage-dependent calcium entry demonstrates the compounds to be potent neurotoxins. This has to be investigated in behavioral and neurophysiological experiments using predator species like sea slugs or others (Wertz et al., 2006).

\section{Acknowledgments}

The sponge collection was carried out by Dr. Michael Assmann during a scientific expedition to the Bahamas in 2000. We would like to acknowledge the support of Prof. Dr. J.R. Pawlik (University of North Carolina at Wilmington, NC) Prof. Dr. T. Lindel (TU Braunschweig), and E. Lichte for preparative HPLC.

\section{References}

Albizati, K.F., Faulkner, D.J., 1985. Stevensine, a novel alkaloid of an unidentified marine sponge. J. Org. Chem. 50, 4163-4164.

Assmann, M., Lichte, E., Pawlik, J.R., Köck, M., 2000. Chemical defenses of the Caribbean sponges Agelas wiedenmayeri and Agelas conifera. Mar. Ecol. Prog. Ser. 207, 255-262.

Assmann, M., Lichte, E., Köck, M., 2004. Multiple defensive roles for bromopyrrole alkaloids from Caribbean Agelas sponges. In: Proceedings of the Sixth International Sponge Conference, Rapallo, Italy, 2002. Boll. Mus. Ist. Biol. Univ. Genova 68, 187-193.

Bernan, V.S., Roll, D.M., Ireland, C.M., Greenstein, M., Maiese, W.M., Steinberg, D.A., 1993. A study on the mechanism of action of sceptrin, an antimicrobial agent isolated from the South Pacific sponge Agelas mauritiana. J. Antimicrob. Chemother. 32, 539-550.

Bickmeyer, U., 2005. Bromoageliferin and dibromoageliferin, secondary metabolites from the marine sponge Agelas conifera, inhibit voltage-operated, but not store-operated calcium entry in PC12 cells. Toxicon 45, 627-632.

Bickmeyer, U., Drechsler, C., Köck, M., Assmann, M., 2004. Brominated pyrrole alkaloids from marine Agelas sponges reduce depolarization-induced cellular calcium elevation. Toxicon 44, 45-51.

Bickmeyer, U., Assmann, M., Köck, M., Schütt, C., 2005. A secondary metabolite from marine sponges of the genus Agelas alters cellular calcium signals. Environ. Toxicol. Pharmacol. 19 (1), 423-427.

Bricelj, V.M., Connell, L., Konoki, K., Macquarrie, S.P., Scheuer, T., Catterall, W.A., Trainer, V.L., 2005. Sodium channel mutation leading to saxitoxin resistance in clams increases risk of PSP. Nature 434, 63-67.

Buchanan, M.S., Carroll, A.R., Addepalli, R., Avery, V.M., Hooper, J.N.A., Quinn, R.J., 2007. Natural products, stylissadines $\mathrm{A}$ and $\mathrm{B}$, specific antagonists of the $\mathrm{P} 2 \mathrm{X}_{7}$ receptor, an important inflammatory target. J. Org. Chem. 72 (1), 2309-2317.

Catterall, W.A., Cestele, S., Yarov-Yarovoy, V., Yu, F.H., Konoki, K., Scheuer, T., 2007. Voltage-gated ion channels and gating modifier toxins. Toxicon 49, 124-141.

Chanas, B., Pawlik, J.R., Lindel, T., Fenical, W., 1996. Chemical defense of the Caribbean sponge Agelas clathrodes. J. Exp. Mar. Biol. Ecol. 208, 185-196.

Fattorusso, E., Taglialatela-Scafati, O., 2000. Two novel pyrrole-imidazole alkaloids from the Mediterranean sponge Agelas oroides. Tetrahedron Lett. 41, 9917-9922.

Fujita, M., Nakao, Y., Matsunaga, S., Seiki, M., Itoh, Y., Yamashita, J., Van Soest, R.W.M., Fusetani, N., 2003. Ageladine A: an antiangiogenic matrixmetalloproteinase inhibitor from the marine sponge Agelas nakamurai. J. Am. Chem. Soc. 125, 15700-15701.

Grube, A., Köck, M., 2006a. Oxocyclostylidol, an intramolecular cyclized oroidin derivative from the marine sponge Stylissa caribica. J. Nat. Prod. 69, 1212-1214.

Grube, A., Köck, M., 2006b. Stylissadines A and B: the first tetrameric pyrrole-imidazole alkaloids. Org. Lett. 8, 4675-4678.

Grube, A., Köck, M., 2007. Structural assignment of tetrabromostyloguanidine: does the relative configuration of the palau'amines need revision? Angew. Chem. Int. Ed. 46, 2320-2324.

Grube, A., Lichte, E., Köck, M., 2006. Isolation and synthesis of 4-bromopyrrole-2-carboxyarginine and 4-bromopyrrole-2carboxy-N(E)-lysine from the marine sponge Stylissa caribica. J. Nat. Prod. 69 (1), 125-127.

Grynkiewicz, G., Poenie, M., Tsien, R.Y., 1985. A new generation of $\mathrm{Ca}^{2+}$ indicators with greatly improved fluorescence properties. J. Biol. Chem. 260, 3440-3450.

Hassenklöver, T., Bickmeyer, U., 2006. The marine secondary metabolites 2,4-dibromophenol and 2,4,6-tribromophenol differentially modulate voltage dependent ion currents in neuroendocrine (PC12)cells. Aquat. Toxicol. 79, 384-390.

Hassenklöver, T., Predehl, S., Pilli, J., Assmann, M., Bickmeyer, U., 2006. Bromophenols, present both in marine organisms and in industrial flame retardants, disturb cellular calcium signaling in neuroendocrine cells (PC12). Aquat. Toxicol. 76, $37-45$.

Kobayashi, H., Kitamura, K., Nagai, K., Nakao, Y., Fusetani, N., van Soest, R.W.M., Matsunaga, S., 2007. Carteramine A, an inhibitor of neutrophil chemotaxis, from the marine sponge Stylissa carteri. Tetrahedron Lett. 48, 2127-2129.

König, G.M., Wright, A.D., Linden, A., 1998. Antiplasmodial and cytotoxic metabolites from the Maltese sponge Agelas oroides. Planta Med. 64, 443-447. 
Llewellyn, L.E., 2006. The behavior of mixtures of paralytic shellfish toxins in competitive binding assays. Chem. Res. Toxicol. 19, 661-667.

Mebs, D., 2002. Venomous and Poisonous Animals. Medpharm Scientific Publishers, 339pp.

Nishimura, S., Matsunaga, S., Fusetani, N., Shibazaki, M., Suzuki, K., Furihata, K., Van Soest, R.W.M., 2003. Massadine, a novel geranylgeranyltransferase type I inhibitor from the marine sponge Stylissa aff massa. Org. Lett. 5, 2255-2257.

Pawlik, J.R., Chanas, B., Toonen, R.J., Fenical, W., 1995. Defenses of Caribbean sponges against predatory reef fish. I. Chemical deterrency. Mar. Ecol. Prog. Ser. 127, 183-194.

Pöverlein, C., Breckle, G., Lindel, T., 2006. Diels-Alder reactions of oroidin and model compounds. Org. Lett. 8, 819-821.
Rivera-Rentas, A.L., Rosa, R., Rodriguez, A.D., De Motta, G.E., 1995. Effect of alkloid toxins from tropical marine sponges on membrane sodium currents. Toxicon 33, 491-497.

Tsukamoto, S., Kato, H., Hirota, H., Fusetani, N., 1996. Mauritiamine, a new antifouling oroidin dimer from the marine sponge Agelas mauritiana. J. Nat. Prod. 59, 501-503.

Urban, S., De Almeida Leone, P., Carroll, A.R., Fechner, G.A., Smith, J., Hooper, J.N.A., Quinn, R.J., 1999. Axinellamines A-D, novel imidazo-azolo-imidazole alkaloids from the Australian marine sponge Axinella sp,. J. Org. Chem. 64, 731-735.

Wertz, A., Rössler, W., Obermayer, M., Bickmeyer, U., 2006. Functional neuroanatomy of the rhinophore of Aplysia punctata. Front. Zool. 3:6. 